\title{
Peningkatan Public Trust dan Pengaruhnya Terhadap Kepatuhan Wajib Pajak di Provinsi Sulawesi Selatan
}

\section{Public Trust growth and The Impact on Taxpayer Compliance in South Sulawesi Province}

\author{
Muhamad Thahir Haning ${ }^{1}$, Hasniati ${ }^{1}$, Mashuri H.Tahili ${ }^{2}$ \\ ${ }^{1}$ Fakultas Ilmu Sosial dan Ilmu Politik Universitas Hasanuddin, Makassar \\ ${ }^{1}$ Fakultas Ilmu Sosial dan Ilmu Politik Universitas Hasanuddin, Makassar \\ ${ }^{2}$ Fakultas Ilmu Sosial dan Ilmu Politik, Universitas Muhammadiyah Luwuk Banggai \\ thahir.haning@gmail.com; hasniati@gmail.com; mashuritahili1971@gmail.com
}

\begin{abstract}
Abstrak
Artikel ini bertujuan untuk menganalisis dan menginterpretasi pengaruh model kepercayaan publik terhadap kepatuhan wajib pajak di Provinsi Sulawesi Selatan. Pendekatan penelitian menggunakan analisis kuantitatif dengan metode survey di tiga area Kantor Pelayanan Pajak yaitu Makassar Selatan, Maros, dan Palopo. Populasi dalam penelitian ini adalah wajib pajak yang telah teregistrasi sebagai wajib pajak, baik pajak orang pribadi dan pajak badan sebanyak 2400 orang. Sampel penelitian menggunakan multistage cluster sampling methods untuk memastikan keterwakilan populasi. Penarikan sampel menggunakan metode stratified random sampling terhadap tiga area penelitian. Rumus Slovin digunakan untuk menetapkan jumlah sampel sebesar $20 \%$ dengan pertimbangan karena populasi yang relatif besar dimana persentase kelonggaran ketelitian kesalahan pengambilan sampel yang masih bisa ditolerir sebesar $\alpha=0,05$. Dengan dasar tersebut, maka sampel dalam penelitian ditetapkan sebanyak 400 responden. Teknik analisis data menggunakan teknik analisis kuantitatif dengan menggunakan persamaan model struktural. Hasil penelitian ini menunjukkan bahwa kepercayaan publik berpengaruh positif dan signifikan terhadap kepatuhan wajib pajak. Kepercayaan publik berpengaruh positif dan signifikan terhadap kepatuhan wajib pajak melalui kinerja pelayanan pajak. Variabel kinerja pelayanan pajak berpengaruh positif dan signifikan terhadap kepatuhan wajib pajak. Faktor pemerintah, faktor resiko, dan faktor kontekstual berpengaruh positif dan signifikan terhadap kepercayaan publik dalam meningkatkan kepatuhan wajib pajak di Provinsi Sulawesi Selatan.
\end{abstract}

\section{Kata kunci : Kepercayaan publik, kinerja pelayanan pajak, kepatuhan wajib pajak}

\begin{abstract}
The aim of this study was to explore, analyze, and interpret the influence of public trust model to the pay taxation compliance in South Sulawesi Province. The study used quantitative analysis approach by using survey method in three different areas of Tax Service Office (TSO), namely TSO of South Makassar, TSO Maros, and TSO Palopo. Population of the study was people who have paid for tax and already registered as the tax payer, both individual or institutional payer by total 2400 persons. To ensure the sample represent population, the multistage cluster sampling methods was used. Next, the stratified random sampling was used to select sample from the areas. Sample size was determined by using Slovin formula by tolerated error sampling was $0.20 \%$ and resulted 400 study participants.
\end{abstract}


Analysis technique used in this study were path analysis and structural model. Result of this study shows that public trust positively affected the compliance of tax payer in South Sulawesi Province. Public trust was a significant contributor for compliance of the people through the tax service performance in this province. The variable of tax service performance is correlated positively with compliance of tax payment. Several factors of government, such as integrity, transparency, and accountability also contribute significantly to public trust. In addition, risk factors, such as security, privacy also influence the public trust. Including individual characteristics, social media, and participation in making decision were related to public trust. The recommendation of this study is an integrated model of public trust can be implemented to increase the compliance of tax payer in order to manage their tax payment in South Sulawesi province. Government factor, risk factor, and contextual factor may influence the public trust and, thus, increase the compliance of the payer in this province.

\section{Keywords: public trust, tax service performance, compliance of tax payer}

\section{A. Pendahuluan}

Agenda reformasi publik dalam bidang perpajakan di Indonesia terus dilakukan pemerintah. Inovasi pelayanan pajak melalui e-tax dengan pendekatan CRM (compliance risk management) yang berfokus pada membangun kepatuhan wajib pajak berkelanjutan. Kebijakan ini semata-mata bertujuan untuk membangun kepercayaan publik, kepatuhan wajib pajak, meningkatkan penerimaan sektor pajak sebagai salah satu sumber keuangan yang dapat menopang APBN (Dirjen Pajak, 2018). Namun, tampaknya kepatuhan wajib pajak masih perlu ditingkatkan, mengingat fenomena rendahnya kepatuhan wajib pajak masih tampak nyata, baik pada level nasional maupun daerah. Argumentasi dalam penelitian ini bahwa untuk meningkatkan kepatuhan wajib pajak dapat dilakukan melalui penerapan model integratif public trust dalam dalam meningkatkan Kepatuhan Wajib Pajak di Provinsi Sulawesi Selatan.

Dalam proyeksi perpajakan tahun 2018, Pemerintah menetapkan target penerimaan perpajakan 2018 sebesar $\mathrm{Rp}$ 1.618,1 triliun atau tumbuh sebesar $10 \%$ jika dibandingkan dengan outlook APBNP 2017, yaitu sebesar Rp. 1.472,7 triliun. Penerimaan tersebut berasal dari penerimaan kepabean dan cukai sebesar Rp 194.1 triliun dan penerimaan pajak sebesar Rp 1.424,0 triliun (Online Pajak, 2018). Pada tahun 2017, realisasi penerimaan perpajakan 2017 adalah Rp. 1.339,8 triliun, sedangkan realisasi penerimaan pajak saja mencapai $\mathrm{Rp}$ 1.147,5 triliun atau $89,4 \%$ dari target APBNP 2017 (Dirjen Pajak, 2017).

Di Provinsi Sulawesi Selatan masih terdapat fenomena menurunnya kepatuhan wajib pajak. Salah satu contoh menurunnya kepatuhan wajib pajak orang pribadi pada KPP Makassar Utara selama tahun 2014 -2016 sebagai berikut:

Tabel 1

Wajib Pajak Orang Pribadi dan Badan Patuh dan Tidak Patuh

\begin{tabular}{|c|c|c|l|}
\hline Tahun \\
Pajak & $\begin{array}{c}\text { Jumlah } \\
\text { WP OP } \\
\text { terdaftar } \\
\text { wajib SPT } \\
\text { Tahunan } \\
\text { PPh }\end{array}$ & $\begin{array}{c}\text { Jumlah } \\
\text { WP OP } \\
\text { Patuh }\end{array}$ & $\begin{array}{l}\text { Jumlah } \\
\text { WP OP } \\
\text { tidak } \\
\text { patuh }\end{array}$ \\
& & \\
\hline 2014 & 70.219 & 51.579 & 18.640 \\
\hline
\end{tabular}




\begin{tabular}{|l|l|l|l|}
\hline 2015 & 72.735 & 36.324 & 36.411 \\
\hline 2016 & 77.942 & 41.217 & 36.725 \\
\hline
\end{tabular}

Sumber: Seksi PDI KPP Makassar Utara, 2017 (Data 2018 belum diupdate)

Berdasarkan data pada tabel tersebut menunjukkan bahwa pada tahun 2014 jumlah WP OP terdaftar (registered) sebanyak 70.2019, tahun 2015 72.735, dan tahun 2016 sebanyak 77.942. Data ini memberikan informasi bahwa jumlah WP OP terdaftar wajib SPT perkembangannya selama tiga tahun terakhir terus meningkat. Namun, jika dilihat dari kepatuhan wajib pajak orang pribadi terus menurun dari 51.579 wajib pajak patuh, tetapi ada 18.640 atau sekitar 73,5\%, tahun 2015 hampir sama sebanyak 36.411 wajib pajak orang pribadi yang tidak patuh atau sekitar 50,1\%, dan tahun 2016 jumlah WP OP patuh sebanyak 41.217, namun jumlah WP OP yang tidak patuh sebesar 36.725 atau $47,7 \%$.

Dalam beberapa dekade terakhir, public trust menarik perhatian para ahli ilmu administrasi publik. Kepercayaan publik merupakan isu yang menjadi kajian utama dalam administrasi publik, ilmu politik, dan ada beberapa ahli yang telah melakukan kajian tentang public trust (Denhardt, 2002; Herzlinger, 1996; Kim 2005), mengingat adanya kecenderungan menurunnya kepercayaan publik dalam organisasi sektor publik (Van de Walle, Van Roosbroek, \& Bouckaert,2008).

Fenomena meningkatnya level distrust kepada pemerintah, maka hal ini menjadi tantangan tersendiri bagi pemerintah untuk meningkatkan legitimasi, daya saing nasional, dan kepatuhan publik terhadap kebijakan pemerintah, sehingga ada kebutuhan yang sangat jelas tentang pentingnya isu mengenai kepercayaan publik (Braithwaite \& Makkai, 1994; Lee, 2003). Dengan demikian, artikel ini bertujuan untuk menganalisis dan menginterpretasikan pengaruh public trust terhadap kepatuhan wajib pajak dengan variabel moderating kinerja pelayanan pajak. Penelitian ini juga menganalisis dan menginterpretasi faktor-faktor determinan yang berpengaruh terhadap kepercayaan publik dalam meningkatkan kepatuhan wajib pajak.

\section{B. Metode Penelitian}

Pendekatan penelitian ini adalah pendekatan kuantitatif dan jenis penelitian ini adalah survey terhadap lokus penelitian yaitu masyarakat (pribadi, badan/privat) yang berada di tiga area Kantor Pelayanan Pajak di Provinsi Sulawesi Selatan yaitu KPP Makassar Selatan, KPP Maros, dan KPP Palopo. Populasi penelitian berjumlah 2400 orang yang telah teregistrasi pada Kantor KPP masingmasing area. Pengambilan sampel menggunakan dua jenis teknik yaitu proportional stratified sampling and the multistage cluster sampling untuk memastikan keterwakilan populasi. Penentuan besaran sampel menggunakan rumus Slovin (Umar, 2003) dengan formula sebagai berikut:

$$
\mathrm{n}=\frac{\mathrm{N}}{1+\mathrm{N} \cdot \mathrm{e}^{2}}
$$

dimana :

$\mathrm{n}=$ Ukuran Sampel (20\%)

$\mathrm{N}=$ Ukuran Populasi

$\mathrm{E}=$ Prosentase $(\%)$ toleransi ketidaktelitian karena kesalahan dalam pengambilan sampel $(\alpha=$ $0,05 \%)$. 
Dengan formula tersebut maka untuk menetapkan jumlah sampel dengan pertimbangan karena populasi yang relatif besar dimana persentase kelonggaran ketelitian kesalahan pengambilan sampel yang masih bisa ditolerir sebesar 0,20\%. Dengan dasar tersebut, maka sampel dalam penelitian ditetapkan sebanyak 400 responden. Instrumen penelitian menggunakan skala Likert dengan kategori tertinggi 4 dan terendah 0 .

Pengumpulan data dilakukan mulai bulan Februari - April 2018 melalui kuesioner yang didesain berdasarkan teori-teori yang relevan dengan fokus penelitian. Seluruh kuesioner yang disebarkan kepada 400 responden di tiga area penelitian, seluruhnya kembali dan tidak ada yang hilang atau cacat. Selanjutnya dilakukan analisis untuk menentukan validitas dan reliabilitas data digunakan teknik analisis alpha Cronbach untuk validitas data, dan untuk analisis menggunakan software Amos Versi 21 untuk mengetahui nilai CR (composite reliability) dan AVE (average variance extracted) dengan nilai yang diharapkan adalah $\geq 0,05$ dan $\mathrm{CR} \geq 0,07$. Hasil analisis ditemukan bahwa keseluruhan item atau konstruk dengan menggunakan standardized faktor loading seluruh item signifikan ( $\mathrm{p}<\cdot 0,05)$. Untuk persyaratan analisis model struktural, maka hasil analisis kami menemukan nilai Cronbach's Alpha sebesar $\geq 0,70$, sehingga persyaratan penggunaan analisis model struktural terpenuhi.

\section{Pembahasan}

Dalam kajian literatur menjelaskan bahwa kepercayaan kepada fungsi pemerintah merupakan prasyarat utama menciptakan kepatuhan masyarakat (Braithwaite \&
Makkai 1994; Lee, 2003). Kepercayaan publik adalah bentuk kepercayaan yang diberikan oleh kelompok atau individu dalam institusi sosial atau sistem (Straten, et al., 2002). Public trust berkaitan dengan perilaku (Parker \& Parker, 1993). Para ahli administrasi publik pada umumnya gagal mengembangkan sebuah model kepercayaan publik yang mengeksplorasi baik dari konsep trust dan ketepatan indikator kepercayaan publik dan implikasinya (Kim, 2005). Dalam meningkatkan keterbukaan pemerintah yang seluas-luasnya atau transparansi dalam pemerintahan menjadi strategi utama untuk menumbuhkan kepercayaan publik (Clark \& Veal, 2011). Berdasarkan pemikiran tersebut, dapat dipahami bahwa ada dua faktor utama dalam menumbuhkan kepercayaan publik yaitu keterbukaan informasi dan transparansi kebijakan pemerintah. Para ahli berpendapat bahwa kepercayaan publik merupakan dimensi penting untuk meningkatkan legitimasi dan kinerja pemerintahan yang demokratis (Putnam 1993). Kepercayaan publik dipandang sebagai salah satu modal sosial yang dapat mendukung kerjasama dan kolaborasi dalam penyelenggaraan pemerintahan yang efektif (Houston, 2012). Dalam literatur menjelaskan bahwa public trust in government dapat meningkatkan kepatuhan publik terhadap implementasi kebijakan pemerintah dan peran pemerintah dalam kebijakan tertentu (Hetherington, 2004; Chanley, Rudolph, dan Rahn, 2000). Kepercayaan publik kepada pemerintah dapat meningkatkan partisipasi dan kepatuhan publik sehingga dapat terwujud tata kelola pemerintahan yang efektif (Kim, 2005). Berdasarkan uraian tersebut dapat dirumuskan hipotesis penelitian sebagai berikut: 
H1: Kepercayaan publik berpengaruh positif terhadap kepatuhan wajib pajak di Provinsi Sulawesi Selatan.

$\mathrm{H} 2$ : Kepercayaan publik berpengaruh positif terhadap kepatuhan wajib pajak membayar pajak melalui kinerja pelayanan pajak di Provinsi Sulawesi Selatan.

Hasil analisis data menunjukkan bahwa data yang digunakan memiliki kelayakan dalam menguji variabel yang diteliti. Hasil uji dengan analisis diperoleh $\mathrm{CMIN}=\mid \mathrm{CMIN}=429,216 ; \quad \mathrm{Sig}=0,0000$; $\mathrm{Df}=98 ;$ Ratio $=4.380 ; \mathrm{CFI}=0.779 ; \mathrm{NFI}=$ 0.735; $\mathrm{PCFI}=0.636$; $\mathrm{PNFI}=0.600$; dan RMSEA $=0.92$. Hasil analisis CFA (Confirmatory Faktor Analysis) menunjukkan bahwa model sudah memenuhi kelayakan dan dapat dilakukan pengujian model persamaan struktural. Hasil analisis Regresi dengan menggunakan teknik analisis SEM dapat dilihat pada tabel berikut:

Tabel 2.

Ringkasan Hasil Analisis Regresi Model Persamaan Struktural

\begin{tabular}{|c|c|c|c|c|c|c|}
\hline & & Estimate & S.E. & C.R. & $\mathrm{P}$ & Label \\
\hline ServicePerform & <... publictrust & .412 & .054 & 7.664 & **** & par_16 \\
\hline government & $<$ <.. publictrust & .451 & .062 & 7.273 & **** & par_10 \\
\hline riskfactors & $<\ldots$ publictrust & .398 & .052 & 7.718 & *** & par_ll \\
\hline contextfactors & $<\ldots$ publictrust & .155 & .048 & 3.227 & .001 & par_12 \\
\hline taxcompliance & $<\ldots$ publictrust & .170 & .045 & 3,756 & *** & par_13 \\
\hline taxcompliance & <.-. ServicePerform & .175 & .059 & 2.961 & .003 & par_17 \\
\hline
\end{tabular}

Sumber: Hasil olahan data, 2018.

Hasil analisis ini menunjukkan bahwa hipotesis 1 (H1) diterima. Penelitian ini memperkuat argumentasi bahwa kepercayaan publik dapat meningkatkan kepatuhan wajib pajak dalam membayar pajak. Penelitian ini sesuai hasil penelitian yang menegaskan bahwa kepatuhan wajib pajak dapat ditingkatkan melalui kombinasi antara power dan trust (Kirchler, Hoelzl, dan Wahl, 2007).
Hasil analisis dilakukan untuk mengetahui pengaruh langsung dan tidak langsung variabel public trust terhadap kepatuhan wajib pajak dapat dilihat pada tabel berikut:

Table 3

Pengaruh langsung dan tidak langsung variabel public trust terhadap kepatuhan wajib pajak

\begin{tabular}{|l|c|c|}
\hline \multirow{2}{*}{ Variable } & Direct & Indirect \\
\cline { 2 - 3 } & publictrust & publictrust \\
\hline Serviceperform & .536 & .000 \\
Contextfact & .200 & .000 \\
Riskfact & .675 & .000 \\
Taxcompliance & .346 & .147 \\
Govern & 1.205 & .000 \\
\hline
\end{tabular}

Sumber: Hasil olahan data, 2018.

Berdasarkan data yang ditunjukkan pada Tabel 3 bahwa kepercayaan publik mempunyai pengaruh positif dan signifikan terhadap kepatuhan wajib pajak baik langsung maupun tidak langsung. Pengaruh langsung variabel public trust terhadap kepatuhan wajib pajak berdasarkan hasil analisis persamaan struktural yang terstandarisasi sebesar 0,346 atau $34,6 \%$ pada taraf signifikansi $\alpha=0,05$. Di samping itu, public trust berpengaruh tidak langsung terhadap kepatuhan wajib pajak berdasarkan hasil pengukuran persamaan struktural sebesar 0,147 atau $14,7 \%$.

Selanjutnya hasil analisis data dalam penelitian ini menunjukkan bahwa ada pengaruh positif dan signifikan kepercayaan publik terhadap kepatuhan 
membayar pajak melalui kinerja pelayanan pajak dengan pengaruh langsung sebesar 0,35 atau $35 \%$, dan pengaruh tidak langsung sebesar 40,5\%. Dengan demikian maka Hipotesis $2(\mathrm{H} 2)$ diterima pada taraf signifikansi $0,05 \%$. Penelitian ini membuktikan pula bahwa da pengaruh positif dan signifikan kinerja pelayanan pajak dengan kepatuhan wajib pajak dengan koefisien pengaruh langsung sebesar 0,27 atau 27\% hasil analisis yang terstandarisasi pada taraf signifikansi $0,05 \%$. Berdasarkan hasil temuan ini dapat dikonfirmasi bahwa variabel public trust berpengaruh positif dan signifikan baik langsung maupun tidak langsung terhadap kepatuhan wajib pajak.

Dalam perspektif public trust, hasil penelitian membuktikan bahwa terdapat hubungan yang positif antara trust terhadap pelayanan publik (Hamm, Hoffman, \& Tomkins, 2016). Kepercayaan publik kepada pemerintah sangat bermanfaat untuk mendorong individu dalam masyarakat untuk memberikan informasi penting tentang masalah yang bersifat pribadi terutama yang berkaitan dengan kinerja pemerintah (Kim, 2005). Berdasarkan teori tersebut, maka dapat dikemukakan hipotesis sebagai berikut:

H3:Kinerja Pelayanan Pajak berpengaruh positif terhadap kepatuhan wajib pajak di Provinsi Sulawesi Selatan.

Berdasarkan hasil analisis data penelitian yang telah dipaparkan pada Tabel 2 menunjukkan bahwa variabel eksogen berpengaruh positif dan signifikan dengan nilai estimate sebesar 0,170 ; standar error 0,045; dan nilai CR 3.756 pada taraf signifikansi $\alpha=0.05$ atau taraf kepercayaan 95\%. Dengan demikian hasil analisis dalam penelitian ini menunjukkan bahwa hipotesis 3 (H3) yang menyatakan bahwa kinerja pelayanan pajak berpengaruh positif terhadap kepatuhan wajib pajak dapat diterima.

Dalam penelitian ini terdapat tiga aspek yang berpengaruh terhadap kepercayaan publik dalam mengembangkan kepatuhan wajib pajak. Hasil analisis membuktikan bahwa ada faktor pemerintah berpengaruh positif terhadap kepercayaan publik dengan koefisien regresi sebesar 0,451 atau $45,1 \%$, Penelitian ini membuktikan bahwa hipotesis empat (H4) bahwa faktor Pemerintah berpengaruh terhadap kepercayaan publik dalam meningkatkan kepatuhan wajib pajak di Provinsi Sulawesi Selatan dapat diterima. Hasil penelitian ini relevan dengan penelitian Kirchler (2007) bahwa masyarakat berusaha untuk mematuhi atau mengingat kewajiban mereka untuk membayar pajak setiap tahun berdasarkan kinerja pemerintah. Penelitian lain menemukan bahwa ada pengaruh positif dan signifikan transparansi sistem perpajakan terhadap kepatuhan wajib pajak melalui kepercayaan (trust) (Siahaan, 2013). Literatur trust menjelaskan bahwa ada korelasi yang kuat antara trust dengan governance. Hal ini dapat dibuktikan dari hasil penelitian yang menegaskan bahwa kepercayaan (trust) dapat meningkatkan partisipasi publik dan kepatuhan (Levi \& Stroker, 2000). Publik atau masyarakat pada umumnya akan patuh terhadap kepentingan atau tuntutan pemerintah dan memberikan mandat sepenuhnya ketika mereka percaya kepada pemerintah (Tyler, 1998). 
Kemudian faktor resiko berpengaruh positif terhadap kepercayaan publik dengan nilai koefisien regresi sebesar 0,398 atau 39,8\%. Hasil penelitian ini membuktikan bahwa hipotesis lima (H5) yakni faktor resiko berpengaruh terhadap kepercayaan publik dalam meningkatkan kepatuhan wajib pajak di Provinsi Sulawesi Selatan dapat diterima. Beberapa peneliti telah melakukan penelitian yang membuktikan bahwa faktor resiko memiliki pengaruh yang kuat terhadap kepercayaan (trust) (Horsburgh et al., 2011; Ayyash et al., 2013).

Hasil analisis juga menemukan bahwa ada pengaruh positif faktor kontekstual terhadap kepercayaan publik dengan koefisien regresi sebesar 0,155 atau $15,5 \%$ pada taraf signifikansi $0,05 \%$. Dengan demikian hipotesis 6 (H6) yaitu faktor kontekstual berpengaruh positif terhadap kepercayaan publik dalam meningkatkan kepatuhan wajib pajak di Provinsi Sulawesi Selatan dapat diterima. Hasil penelitian ini relevan dengan hasil penelitian sebelumnya yang menemukan bahwa faktor kontekstual meliputi karakteristik individu, penyelenggara sistem layanan pajak, modal sosial, dan pengaruh media. Forster \& Nilakant (2005) menegaskan bahwa trust adalah dimensi mekanisme sosial yang sangat penting untuk menciptakan tata kelola kepemerintahan yang efektif dan efisien, sehingga biaya pengawasan atau campur tangan pemerintah dapat dikurangi. Ketika pemerintah mampu memberikan kepuasan terhadap apa yang dibutuhkan masyarakat, maka akan dapat membangkitkan trust, tidak hanya melihat input dan output yang dicapai pemerintah.
Selanjutnya dapat digambarkan model integratif public trust dalam peningkatan kepatuhan wajib pajak di provinsi Sulawesi Selatan dapat digambarkan sebagai berikut:

\section{Gambar 1.}

Model integratif public trust dalam meningkatkan kepatuhan wajib pajak

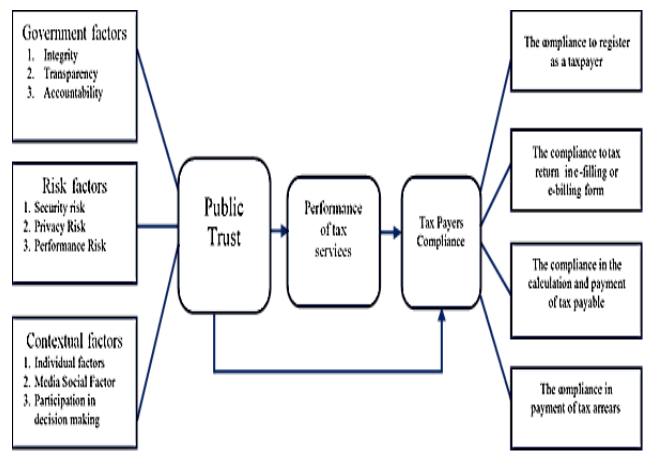

Kajian tentang kepatuhan masyarakat terhadap kebijakan pemerintah bahwa ada empat faktor utama yang dapat mempengaruhi public trust kepada pemerintah dan memerlukan studi tindaklanjut yang lebih mendalam (Berman, 2000; Kim, 2005; Mayer, Davies, \& Schoorman, 2007). Trust kepada pemerintah dapat meningkatkan kerjasama antar-pemerintah dengan masyarakat dan menumbuhkan kepatuhan masyarakat terhadap kebijakan publik yang ditetapkan pemerintah (Lee \& Yu, 2013).

Trust dapat dipengaruhi oleh faktor kemampuan yang dimiliki aparatur pemerintah, kerelaan yakni kesediaan masyarakat untuk patuh terhadap peraturan atau kebijakan yang ditetapkan pemerintah, dan integritas dimana pelayanan pajak yang diberikan pegawai dilandasi oleh persahabatan (faithful) dan keadilan serta kejujuran (Mayer, Davis, \& Schoorman, 2007; Colquite, et.al 2007). 
Dengan demikian public trust merupakan salah satu faktor yang perlu dipertimbangkan dalam meningkatkan kepatuhan wajib pajak, dan juga kepercayaan publik dapat berpengaruh positif terhadap kinerja pelayanan pajak di Provinsi Sulawesi Selatan.

\section{Kesimpulan}

Berdasarkan hasil analisis data menemukan bahwa model integratif kepercayaan publik berpengaruh signifikan terhadap kepatuhan wajib pajak di Provinsi Sulawesi Selatan yang menggunakan responden yang tersebar di tiga wilayah Kantor Pelayanan Pajak di Provinsi Sulawesi Selatan yaitu KPP Makassar Selatan, KPP Maros, dan KPP Palopo. Kesimpulan dalam penelitian ini adalah sebagai berikut:

1. Kepercayaan Publik berpengaruh positif dan signifikan baik langsung atau tidak langsung terhadap kepatuhan wajib pajak melalui membayar pajak di Provinsi Sulawesi Selatan.

2. Kepercayaan Publik berpengaruh positif terhadap kinerja pelayanan pajak di Provinsi Sulawesi Selatan.

3. Kinerja pelayanan publik berpengaruh positif dan signifikan terhadap kepatuhan wajib pajak di Provinsi Sulawesi Selatan.

4. Faktor Pemerintah yang terdiri dari tiga indikator yaitu integritas, transparansi, dan akuntabilitas memiliki pengaruh positif dan signifikan terhadap kepercayaan publik.

5. Faktor resiko yang terdiri dari tiga indikator yaitu resiko keamanan, resiko privacy, dan resiko kinerja berpengaruh positif terhadap kepercayaan publik.

6. Faktor kontekstual yaitu karakteristik individual, media sosial, dan partisipasi dalam pengambilan keputusan berpengaruh positif terhadap kepercayaan publik.

Dalam penelitian ini ada keterbatasan dari sisi metode pengambilan sampel, dan analisis yang kompleks sehingga ada kecenderungan pengaruh koefisien regresi sangat rendah. Oleh karena itu, penelitian selanjutnya dapat dikembangkan lebih jauh dengan meneliti kepatuhan wajib pajak yang lebih khusus kepada pajak badan atau organisasi privat, karena dalam penelitian ini menggunakan responden dari seluruh wajib pajak yang telah teregistrasi pada Kantor Pelayanan Pajak.

\section{Daftar Pustaka}

Alzahrani, L., Al-Karaghouli, W., \& Weerakkody, V, 2017. Analysing the critical factors influencing trust in e-government from Citizens perspective: A systematic review and conceptual model, International business review, Vol.26, Issue 1, pp. 164-175.

Ayyash, M. Ahmad, K. \& Singh, D., 2013. Investigating the Effect of Information Systems Factors on Trust in E-Government Initiative Adoption in Palestinian Public Sector. Research Journal of Applied Sciences, Engineering and Technology, Vol. 5, No. 15, pp. 3865-3875.

Chanley, V.A., Rudolph, T., \& Rahn, 2000. The Origins and Consequences of Public Trust in 
Government. Public Opinion Quarterly, Vol. 64, No. 3, pp. 239256.

Clark, C., \& Veal, D-T., 2011. Advancing Excellence and Public Trust in Government, Lexington Books, Rowman \& Littlefield Publishers, Inc., New York.

Direktorat Jenderal Pajak. 2017. Informasi Reformasi

Perpajakan, www.pajak.go.id. Diakses 15 Juni 2018.

Forster, T.H., \& Nilakant, V,. 2005. Role of Trust in Privatization: Transformation of the Electricity Utility in Gambia. The Journal of Behavioral Science, Vol. 41, No. 3, pp. 348-366.

Gunadi, 2013. PanduanKomprehensif Pajak Penghasilan, Bee Media Indonesia, Jakarta.

Hamm,J.A,2017.Trust,Trustworthi-ness, and Motivation in the Natural Resource Management Context, Journal Society \& Natural Resources: An International Journal, Vol. 30, Issue 8, pp. 919-933.

Herzlinger, R.E., 1996. Can public trust in nonprofits and government be restored? Harvard Business Review, Vol. 74, No. 2, pp. $97-107$.

Hetherington, M.J. 2004. Why Trust Matters: Declining Political Trust and the Demise of American Liberalism Princeton. Princeton University Press.

Horsburgh, S., Goldfinch, S., \& Gauld, R., 2011. Is Public Trust in Government Associated With Trust in E-Government? Social Science Computer Review, Vol. 29, No. 2, pp. 232-241.
Houston, D.J., \& Harding, L.H., 2013. Public Trust in Government Administrators Explaining Citizen Perceptions of Trustworthiness and Competence, ASPA, Public Integrity, Winter, Vol. 16, No. 1, pp. 53-75.

Jackson, B. R., \& Milliron, C.V., 1986. Tax compliance research: Findings, problems and prospects. Journal of Accounting Literature, Vol. 5, pp. 125-165.

James, S., \& Alley, C., 2002. Tax compliance, self assessment system and tax administration. Journal of Finance, and Management in Public Services, Vol.No.2, pp, $27-42$.

Kim, S.E., 2005. The role of trust in the modern administrative state: An integrative model.

Administration \& Society, Vol. 37, No. 5, pp. 611-635.

Kirchler, E. 2007.The economic psychology of tax behaviour. In MisuBarbuta, 2011. A Review of Faktor s for Tax Compliance, EAI, Annals of "Dunarea de Jos" University of Galati Fascicle I. Economics and Applied Informatics, Years XVIINo. 1/2011; ISSN 1584-0409,

Kirchler, E., Hoelzl,E., \& Wahl, I., 2007. Enforced versus voluntary tax compliance: The "slippery slope" framework, ScienceDirect, Journal of Economic Psychology, Vol. 29 pp. 210-225.

Lee, A.R., 2003. Down and down we go: Trust and compliance in South Korea, Social Science Quarterly, Vol. 84, No. 2, pp. 329-343.

Lee, S.J., \& Yu, H.J., 2013. Faktor s Affecting Public Servants' Trust In Citizens: A Case Study of South 
Korean Central Government Officials, International Review of Public Administration, Vol. 18, No.3, pp. 85-113.

Levi, M. \& Stoker, L. 2000. Political trust and trustworthiness. Annual Review of Political Science, Vol. 3, hal. 475507.

Mayer, R.C., Davis, J.H., \& Schoorman, F.D., 2007. An integrative model of organizational Trust: Past, Present, and Future, Academic Management Review, Vol. 32, pp. 344-354.

Mousavi, S.A., \& E. Pimenidis, E., 2014. Social Media Applications in eGovernment: A Risk Assessment Approach, Paper presented in $14^{\text {th }}$ European Conference on eGovernment, Romania, 2014.

Parker, S.L. \& Parker, G.R., 1993. Why do we trust our congressman?, Journal of Politics, Vol. 55 No. 2, pp. 442-453.

Putnam, R.P., 1993. Making Democracy Work: Civic Traditions in Modern Italy. Princeton, Princeton University Press, MJ.

Putnam, R. 1995. Tuning in, tuning out: the strange disahal earance of social capital in America. Political Science and Politics, Vol. 28, No. 4, pp. 664 -683 .

Rudolph, T.J., \& Evans, J., 2005. Political Trust, Ideology, and Public Support for Government Spending. American Journal of Political Science, Vol. 42, pp. 398-417.

Siahaan, F.O.P., 2013. The Effect of Tax Transparency and Trust on Taxpayers' Voluntary Compliance, Journal on Business Review, Vol. 2, No. 3. pp. 3-8.
Straten, G.F., Friele, R.D. \& Groenewegen, P.P., 2002. Public trust in Dutch health care, Social Science and Medicine, Vol. 55, No. 2, pp. 227-234.

Tyler, T.R. 1998. Trust and democratic governance. In A. Braithwaite \& M. Levi (Eds.), Trust and governance, Russell Sage, New York, pp. 269-294.

Umar, H., 2003. Riset Pemasaran dan Perilaku Konsumen, Gramedia Pustaka Utama, Jakarta.

Van de Walle,S., Van Roosbroek, S., \& Bouckaert, G., 2008. Trust in the public sector: is there any evidence for a long-term decline? International Review of Administrative Sciences, SAGE Publications, Vol. 74, No. 1, pp. 47-64. 